\title{
Rompalina
}

(8)

\section{Pericles in Thucydides}

\author{
Autor(es): Rusten, Jeffrey \\ Publicado por: Imprensa da Universidade de Coimbra \\ URL \\ persistente: \\ URI:http://hdl.handle.net/10316.2/32559 \\ DOI: \\ DOl:http://dx.doi.org/10.14195/978-989-26-0442-8_1
}

Accessed : $\quad$ 26-Apr-2023 12:01:58

A navegação consulta e descarregamento dos títulos inseridos nas Bibliotecas Digitais UC Digitalis, UC Pombalina e UC Impactum, pressupõem a aceitação plena e sem reservas dos Termos e Condições de Uso destas Bibliotecas Digitais, disponíveis em https://digitalis.uc.pt/pt-pt/termos.

Conforme exposto nos referidos Termos e Condições de Uso, o descarregamento de títulos de acesso restrito requer uma licença válida de autorização devendo o utilizador aceder ao(s) documento(s) a partir de um endereço de IP da instituição detentora da supramencionada licença.

Ao utilizador é apenas permitido o descarregamento para uso pessoal, pelo que o emprego do(s) título(s) descarregado(s) para outro fim, designadamente comercial, carece de autorização do respetivo autor ou editor da obra.

Na medida em que todas as obras da UC Digitalis se encontram protegidas pelo Código do Direito de Autor e Direitos Conexos e demais legislação aplicável, toda a cópia, parcial ou total, deste documento, nos casos em que é legalmente admitida, deverá conter ou fazer-se acompanhar por este aviso. 
Aurelio Pérez Jiménez, Joșé Ribeiro Ferreira

e Maria do Céu Fialho

(COORdinadores)

\section{Adminiftri Principum.}

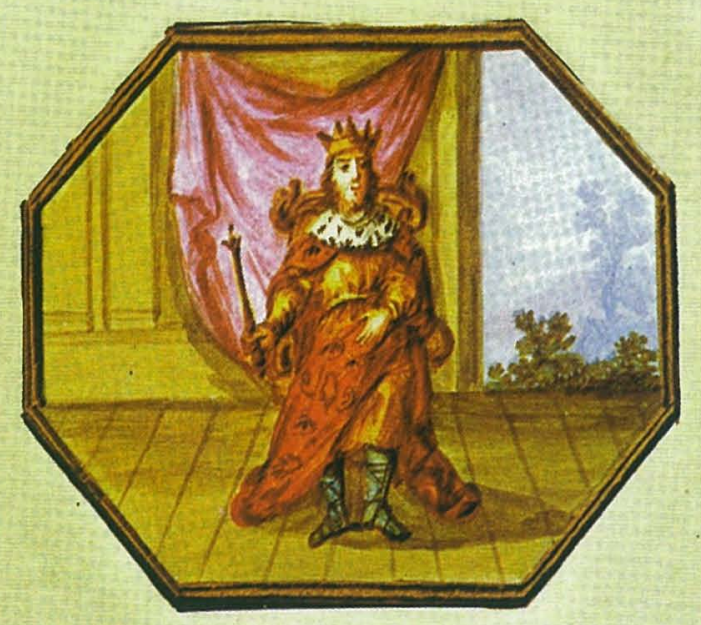

\section{EMBLEM A LIV.}

En tibi plura gerit, quàm lumina prabuit Argos Rex; Aures totidem, quin totidemó, manus. Hec opus Imperio, fidis fupplenda Minijtris, Regi bi funt aures: lumina clara, manus.

\section{- Retrato e a Biografia como estratégia de teorização política}

IMPRENSA DA UNIVERSIDADE DE COIMBRA

Universidad de MálaGa 
(Página deixada propositadamente em branco) 
Aurelio Pérez Jiménez

José RIBEIRo FERREIRA

Maria do Céu Fialho

O RETRATO LITERARIO E A BIOGRAFIA COMO ESTRATÉGIA

\section{DE}

TEORIZACCÃO POLITICA

IMPRENSA DA UNIVERSIDADE DE COIMBRA

UnIVERSIDAD DE MÁlaGa

2004 
Obra publicada com a colaboração de:

Centro de Estudos Clássicos e Humanísticos (Universidade de Coimbra)

International Plutarch Society

Primera edição, Junho de 2004

(c) IMPRENSA DA UnIVERSIDADE DE COIMBRA

(c) Área de Filología Griega. Universidad de Málaga

Coordenação editorial:

Imprensa da Universidade de Coimbra

Área de Filología Griega de la UMA

ISBN: 972-8704-25-9 (PORTUGAL)

ISBN: 84-608-0166-7 (ESPANHA)

Depósito Legal: MA-1420

Impresso em Espanha

Execução gráfica:

IMAGRAF IMPRESORES, S.A.

c/ Nabucco 14

29006 Málaga

Tfno. 952328597

Página de rosto:

"Dos Princepes Transùmptos verdadeiros": Francisco António Novaes Campos, Principe perfeito. Emblemas de D. Joâo de Solórzano. Edição fac-similada do manuscrito da Biblioteca Nacional do Rio de Janeiro oferecido ao Príncipe D. João em 1790 (Prefácio, introdução, comentário e índices por Maria Helena de Teves Costa Ureña Prieto), Instituto de Cultura e Língua Portuguesa, Lisboa, 1985, Emblema LIV, p. 114. 


\title{
Pericles in ThuCYdides ${ }^{1}$
}

\author{
Jeffrey Rusten \\ Cornell University
}

\section{The importance of Individuals in Thucydides' History}

Why does one write a biography rather than a history? To start with, it is obviously much easier to know where to begin and end! But there might be more profound reasons as well, for example:

- a belief in the all-encompassing power of an individual leader to affect history (whether a king, an emperor or a president);

- a desire to pass on gossip and anecdote about the famous;

- to collect examples of character to avoid and emulate, or to argue a thesis about the effect of education or natural talent on crucial decisions.

At first Thucydides as historian might seem very far from these motives -his field is human history in general, ta anthropina, not the individuals. He says his aim is to assist those who want to try to understand the events of any time and place, and he deals with abstractions of military strategy and political leadership, material wealth, and above all economic and political power. His whole approach seems to insist that it is factors like these, not any single leader, who makes a difference in history.

1 Even though Pericles is rightly considered the central figure of Thucydides' history, I must confess that I had never thought of Thucydides' portrait of Pericles in terms of a biography, and so it was a very interesting challenge to be asked to do so. I am grateful to the Center of Classical and Humanistic Studies and to the Institute of Classical Studies at the University of Coimbra and especially to Prof. Maria de Fátima Silva for the invitation, kind hospitality and a stimulating discussion. 
Yet it is a paradox that Thucydides' individual portraits are some of the most vivid in Greek literature. One thinks of the hapless Nicias in Sicily especially, but also of Brasidas and Cleon, and the arrogant and brilliant Alcibiades. He sometimes even writes small "obituaries" after individuals' deaths, attempting some general comment about their characters. H. D. Westlake's book Individuals in Thucydides (Cambridge 1968) analyzes all these portraits and comes up with the theory that, as his work progressed, Thucydides assigned increasing importance to the strengths or (more often) the weaknesses of individual leaders. That is an interesting thesis, and it may well be that whereas the Pericles and Cleon of Thucydides are his own creations for his own purposes, the foibles of Nicias and Alcibiades are drawn from life. I would like to test that theory with the one character most closely identified with Thucydides' work.

\section{Writers about Pericles other than Thucydides ${ }^{2}$}

Pericles provides a perfect subject for biography. His career had many different stages, from his first appearance as choregos for Aeschylus' Persians in 472, to his struggle against Cimon and later against Thucydides of Melesias, his legal changes in the Areopagus, the citizenship law, then finally to the rise of the empire and the outbreak of the Peloponnesian war. Not only did he go from success to success, he also represented the spirit of the age:

- intellectually: he is linked with Sophocles and Anaxagoras, and probably responsible for the initial program of public buildings.

- chronologically: his active career spanned the years just after the Persian war to the opening of the Peloponnesian war.

- politically: he came from an aristocratic background but became a champion of the demos.

It did not hurt that he had a turbulent personal life, with plenty of scope for lurid gossip!

Thucydides is not at all our only source for the career of Pericles. He was already one of the subjects for what might be called the first Greek biographical essay, by

2 On Pericles' career the literature is vast; the best place to begin is Plutarch's Life of Pericles, with the excellent commantary by of Philip Stadter, Commentary on Plutarch's Pericles (Chapel Hill, North Carolina 1989), and the articles collected by Gerhard Wirth, Perikles und seine Zeit (Darmstadt 1979) with the bibliography 535559. On T.s own, more limited, portrait of Pericles see especially Westlake, Individuals 23-42, M. Chambers, 'Thucydides and Pericles', H.S.C.P. 72(1957) 79-92 (= Wirth, Perikles 162-177), and 2.65nn. 
Stesimbrotus of Thasos, who was a contemporary of Pericles, and wrote a work entitled "On Themistocles, Thucydides (son of Melesias), and Pericles", which seems to have been very hostile to Pericles and perhaps instead pro-Cimon ${ }^{3}$.

But not all judgments were negative: the comic poet Eupolis, who usually attacked politicians like Alcibiades and Hyperbolus mercilessly, actually wrote a play called "The Demes" in which he called back the great leaders of Athens' past from the dead to save the city at a time of crisis (perhaps after the defeat of the Sicilian expedition, but the date is uncertain). He chose one leader from each generation: Solon from archaic Athens, Miltiades from Marathon, Aristides (NOT Themistocles) from Salamis and finally Pericles. It is striking that little more than a decade after his death, while the war was not yet resolved, Pericles could be ranked in such great company ${ }^{4}$.

Somewhat younger than Thucydides was Plato, whose Gorgias (515D-516D) ends with a harsh condemnation of Pericles (along with Cimon and Themistocles) as rhetoricians who merely pandered to the mob; he implies (by omission) that only Aristides was worthy of praise.

Finally we have the great biography of Pericles by Plutarch, which was written 500 years after Pericles' lifetime, but is less tendentious and more diverse than any other account. Plutarch compares Pericles with the Roman Fabius "Cunctator" because their military strategies were similar; but he also draws on old comedy and Stesimbrotus to give us much miscellaneous information about his politics and rise to power, and some gossip about Pericles' personal life.

Clearly Pericles has never lacked for writers who admired or criticized or at least described him. How do these accounts compare to Thucydides? We will find, to our surprise, that there are almost no common features between them. Thucydides goes in an entirely different direction.

\section{Thucydides' introduction of Pericles and his first speech}

The first book of Thucydides' History is a mixture of many different topics and narrative styles. But two of its major tasks are to present the military conflicts which

3 FGrHist 107 F 1-11, see also Tsakmakis, Antonis. "Das historische Werk des Stesimbrotus von Thasos." Historia 44 (1995): 129-52. Among other things it claimed that Pericles had slept with his daughter in law.

4 Of course, Cratinus and Aristophanes were much more negative in their reaction to Pericles. See the recent book by Michael Vickers, Pericles on Stage (Austin Texas 1997) and Joachim Schwarze, Die Beurteilung des Perikles durch die attische Komödie (Zetemata vol. 51, Munich 1971). 
preceded the war, and give the arguments, by speakers on both sides, for and against going to war. Throughout this long debate, part of which takes place in Athens (when the Corcyreans come to ask for an alliance) and part in Sparta (but with Athenians being allowed to speak), Pericles plays no role whatsoever. In fact, for most of book 1 , Athens might appear to have no individual leader at all, their speeches delivered by unnamed representatives and their decisions made as a group. Pericles is mentioned only in the so-called "Pentekontaeteia" (which summarizes Spartan-Athenian conflict for 480-430), and then only as a general, leading troops and ships against Sicyon (1.111.2), and to put down rebellions at Euboea (1.114) and Samos (1.116-117).

$\mathrm{He}$ is mentioned one other time as well: in the Spartans' diplomatic games over the descendants of the Cylonian conspirators, he is the target of their bargaining, because it is judged his exile would help them in the war (1.127.1).

Yet many political and military issues are debated in book 1 on which Pericles would have had strong opinions, questions like: what should Athens do to assist Corcyra, and will this bring war with Sparta? Should the Spartans decide that Athens has broken the previous peace treaty and declare war, or continue to negotiate? Is Athens a threat to all of Greece? Do the Peloponnesians have the resources and the will to defeat Athens, or is Athens invincible? By the end of book 1, many different opposing viewpoints have been expressed on these questions in many speeches, and the Spartans have come up with two demands to make of Athens for remaining at peace: letting all Greek states be autonomous, and lifting the so-called Megarian decree. Athens needs to do only these two things to avoid war.

At this point, just before Pericles' introduction comes a significant digression about the end of the Persian war that starts out being about the Spartan general Pausanias but turns into one about the Athenian Themistocles, which includes this very unexpected praise of his leadership skills, which constitutes Thucydides' first "obituary":

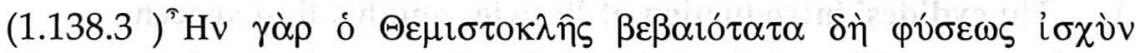

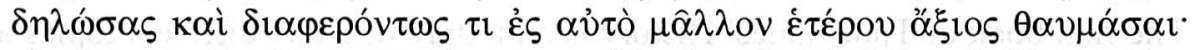

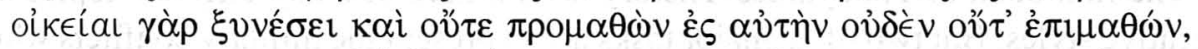

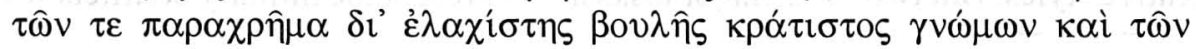

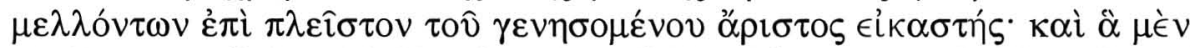

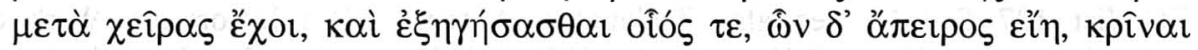

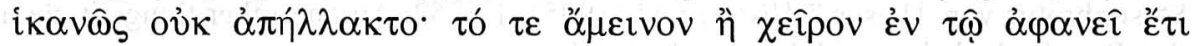

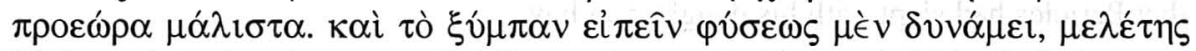

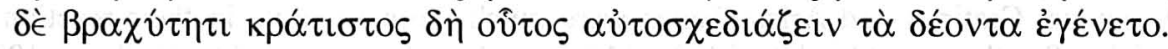

For Themistocles was a man who exhibited the most indubitable signs of genius; indeed, in this particular he has a claim on our admiration quite 
extraordinary and unparalleled. By his own native intelligence, alike unformed and unsupplemented by study, he was at once the best judge in those sudden crises which admit of little or of no deliberation, and the best prophet of the future, even to its most distant possibilities. Able to explain all that came within the sphere of his practice, he was not without the power of passing an adequate judgment in matters in which he had no experience. He could also excellently divine the good and evil which lay hid in the unseen future. In fine, whether we consider the extent of his natural powers, or the slightness of his application, this extraordinary man must be allowed to have surpassed all others in the faculty of intuitively meeting an emergency. (Translation Crawley, slightly adapted)

This passage is resonant with implicit comparison to future leaders, and in the

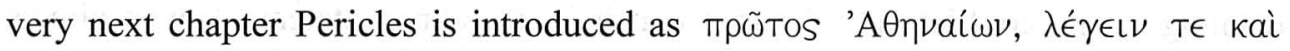

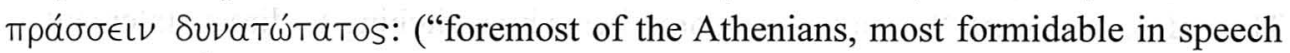
and action" $)^{5}$. The speech he gives is wide-ranging and makes many references to what has been said before now:

- He insists that his policy has always been consistent and should be followed regardless of Sparta's threats;

- He derides Sparta's negotiations and demands as mere tricks to gain time (and in fact we have been told earlier by Archidamus and Thucydides himself that this is true);

- He acutely diagnoses the difficulties that Sparta will have in the war, and finally

- Reveals the strategy he plans to pursue in the war: to treat Athens as an island, never confronting Sparta in a land battle but rather abandoning the countryside while retaining the sea as their theater of military action.

His view is adopted by the Athenians, who decide for war.

It is important to emphasize how different this section is from the rest of book 1: a man who has not taken part in the direct action yet, suddenly gives a speech in which he shows that he understands the Spartan strategy- it is almost as if he has read all the debates at Sparta and Corinth! and reveals an Athenian strategy that will defeat it $^{6}$.

5 But note the prominence of gess.

6 Archidamus understands this strategy too, but unlike Pericles he is unable to persuade his people do what is needed to counter it. 
Even more strikingly, he speaks unopposed, which is unthinkable in Thucydides for a decision of such magnitude as peace vs. war. It is as if all the discordant arguments of book 1 and all the multiple causes of the war have been summarized, then swept aside. The appearance of Pericles is the signal for the end of this first phase, and the beginning of the war itself.

\section{Pericles in the first year of the war}

Pericles' next appearance (2.13) fulfills a promise that he made in his first speech, to give a detailed list of Athens' resources for the war, which he does in indirect statement. this speech is dry and factual, and serves Thucydides' purposes more than any of Pericles: it allows the historian to give crucial information at the opening of the conflict, and the fact that it is in indirect statement even allows Thucydides to insert "footnotes" on some items by switching to direct statement.

We then see (2.14-17) that Pericles' strategy is in fact not without difficulties: during the first year of invasion he has alienated the farmers whose land has been abandoned, as well as the Acharnians whose deme has been singled out for devastation. Yet we can see from the contrast with Aristophanes' play on the same subject how differently Thucydides presents the situation: in Aristophanes, Pericles is a selfish and willful despot who is indifferent to the sufferings of common people, whereas in Thucydides he is a wise leader who understands what is best for the people and is able to keep them from making mistakes?

\section{Pericles' ideal city in the funeral oration}

I have discussed the funeral oration in great detail in my commentary on book $2^{8}$, so I will not try to do justice to all of its contents here. But we should not overlook several unusual features of it for the portrait of Pericles:

1) Placement ${ }^{9}$ : The first year of the war was not notable for great casualties, and in fact was largely a military success. Although Thucydides tells us that the oration was delivered every year, he never mentions it again, so it seems to be placed here (just ahead of the plague) for a reason. It is the last time such praise could have been

7 Thucydides 2.22.1 says that he even somehow avoided calling meetings of the assembly. The picture of Platon, Gorgias, is very different, that Pericles in fact pandered to the people and never resisted them.

J. S. Rusten, Thucydides, The Peloponnesian War Book II (Cambridge, 1989).

9 Its placement here was in fact criticized by Dionysius of Halicarnassus, On Thucydides 18. 
spoken, and the last time by Pericles.

2) Pericles had already given a funeral oration for the war-dead in the campaign against Samos ten years before; on that occasion he expressed sadness at the loss of the young men as equivalent to "losing the spring out of the year" such sympathy here; nor do his harsh words to the women at the end of the speech correspond with what we know of his attitude to his wife Aspasia or his citizenship law, which made mothers as important as fathers in determining citizenship ${ }^{11}$.

3) In his account of Athenian culture and government, which is characterized especially by the harmony of its different systems and avoidance of any kind of excess, many of his factual statements seem questionable- he seems rather to give an ideal vision of what Athens might be, more than what it actually is ${ }^{12}$.

4) Pericles here focuses not on Athens' past as in other speeches, but entirely on its present glory; most surprisingly, he considers Athens supreme achievement to be not its culture or its government, but its power ${ }^{13}$.

\section{Pericles' last speech}

After the funeral oration we move from triumph to misery, from confidence to despair, as the plague strikes Athens with particular force and results in many deaths (eventually that of Pericles himself). This juxtaposition has often been seen as Thucydides' attempt to undercut and subvert the rhetoric of Pericles' speech, and Thucydides certainly means to show Pericles' plans under challenge. Yet he does not remove Pericles from the narrative at this point; rather, he gives him one final speech, which is more revealing about himself and his conception of power and empire than any that has gone before.

Aristotle, Rhetoric 1.1365 a

11 See Aristotle Constitution of Athens, 27, Cynthia Patterson, Pericles Citizenship Law of 451-50 B. C. (Salem, New Hampshire 1971).

Similarly Abraham Lincoln, in his "Gettysburg Address" at a war-burial in 1864, Gettysbuirg address, which opens with a brief history of American government that implies a view of where it is coming next that is much more clear and decisive than any expressed before. See Garry Wills, Lincoln at Gettysburg : the words that remade America (New York 1992), with comparisons to Thucydides.

13 Studied in chapter 5 of the dissertation (University of Algarve, 2001) by Adriana Manuela de Mendonça Freire Nogueira, The Philosophy of Power: Nomos and Physis and the Rule of the Stronger in Thucydides (in Portuguese). 
Pericles decides to defend himself when he is under attack: Thucydides does all he can to suppress the details: he offers only Pericles' own defense, in which there are two implicit throwbacks to his first speech. The first is noted by Thucydides himself, that he remains unchanged, whereas they, the people, alter their views according to circumstances (2.59):

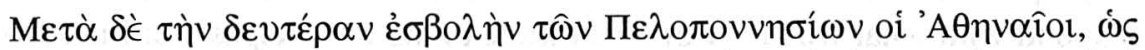

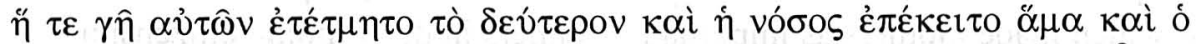

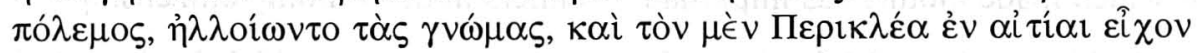

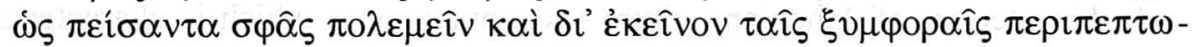

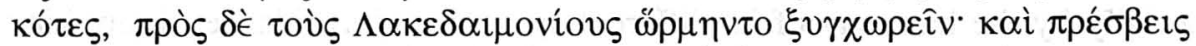

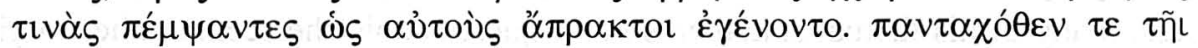

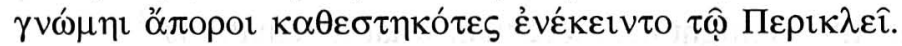

After the second invasion of the Peloponnesians a change came over the spirit of the Athenians. Their land had now been twice laid waste; and war and pestilence at once pressed heavy upon them. They began to find fault with Pericles, as the author of the war and the cause of all their misfortunes, and became eager to come to terms with Lacedaemon, and actually sent ambassadors thither, who did not however succeed in their mission. Their despair was now complete and all vented itself upon Pericles. (transl. Crawley)

It is a fine demonstration of consistency that, despite the plague and the hostility of the public, Pericles claims actually to have foreseen their anger. His defense of the empire and city even during the ravages of the plague is strikingly unemotional (as in the Funeral Oration)- one might even call him callous toward the losses of the people- but at the same time it is resolutely rational and even detached. At the moment that public hysteria is highest, Pericles calmly reminds them the city is stronger than any of them as individuals, that only a percentage of them will die in the plague, whereas if they abandon the city they will all be lost. Pericles' tone in remonstrating with the Athenians is exactly the opposite of Cleon's later, who will always rely on emotional fury to make his point ${ }^{14}$.

The second throwback to the first speech recalls Thucydides' use of Themistocles in introducing it to make an implicit comparison with the future leader-

If I may make a less serious comparison, the contrast between the rational Pericles and the hothead Cleon reminds me of the opposing advisors to the captain in Star Trek- the excitable Dr. McCoy and the super-rational Mr. Spock. Like the Athenians, it was Captain Kirk's job to decide who was right. Perhaps a mor serious analogy would be the duel between reason and spirit in the Platonic soul (Rep. 4.439e-441b). 
ship of Pericles. In this last speech, it is Pericles himself who praises his own qualities as a leader and defines them (2.60.5):

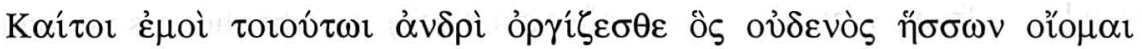

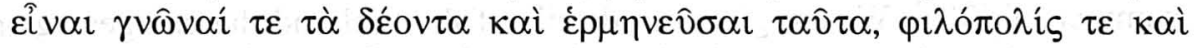

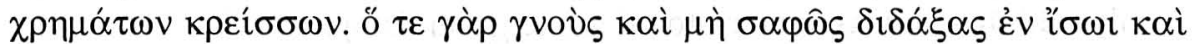

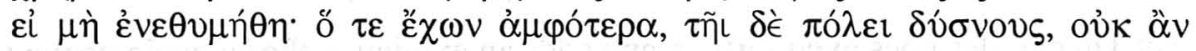

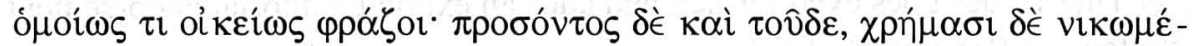

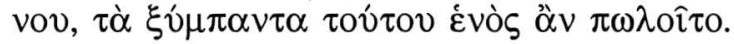

And yet if you are angry with me, it is with one who, as I believe, is second to no man either in knowledge of the proper policy, or in the ability to expound it, and who is moreover not only a patriot but an honest one. A man possessing that knowledge without that faculty of exposition might as well have no idea at all on the matter: if he had both these gifts, but no love for his country, he would be but a cold advocate for her interests; while were his patriotism not proof against bribery, everything would go for a price. (transl. Crawley)

Once again the qualities of a leader can be compared with later politicians (as with Themistocles in Book 1, but now the definition of good leadership is made to apply universally.

At the end of the speech, Thucydides gives the popular reaction (2.65.2-4):

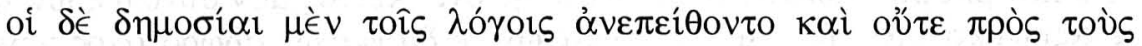

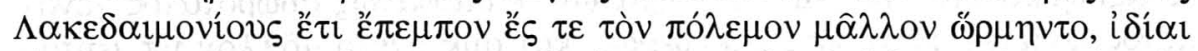

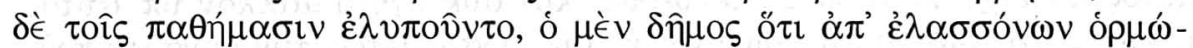

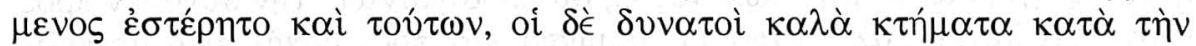

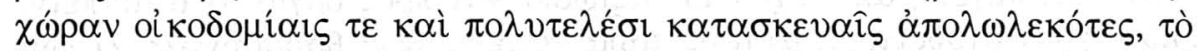

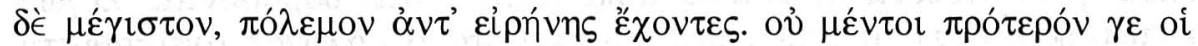

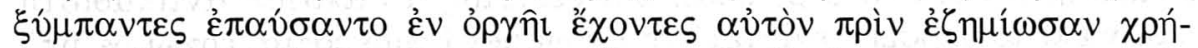

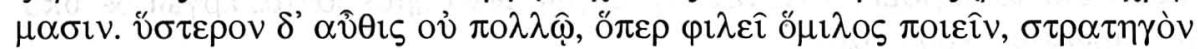

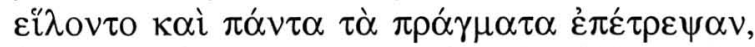

As a community he succeeded in convincing them; they not only gave up all idea of sending to Lacedaemon, but applied themselves with increased energy to the war; still as private individuals they could not help smarting under their sufferings, the common people having been deprived of the little that they were possessed, while the higher orders had lost fine properties with costly establishments and buildings in the country, and, worst of all, had war instead of peace. In fact, the public feeling against him did not subside until he had been fined. Not long afterwards, however, according to the way of the multitude, they again elected him general and committed all their affairs to his hands (trans1 Crawley) 
Once again we can see that Thucydides is not telling us the whole story: he mentions only in passing that Pericles at this time was widely reviled as a war-monger (as we know from Acharnians, even after his death), and that he was put on trial in the summer of $430^{15}$. We are given no details of the trial and the charges against him, only told that he was soon restored to the generalship.

But Thucydides goes even further, and adds an explicit authorial endorsement of the strategy of Pericles (2.65.5-9):

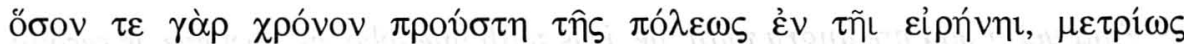

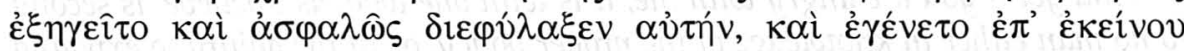

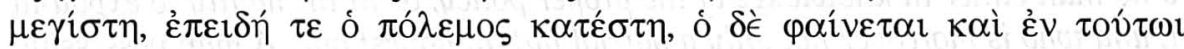

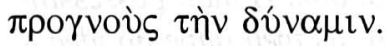

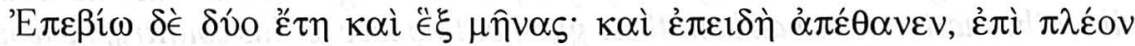

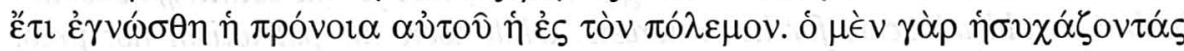

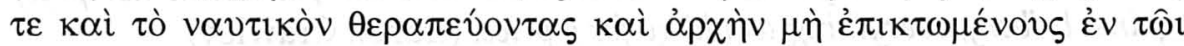

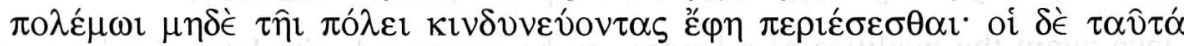

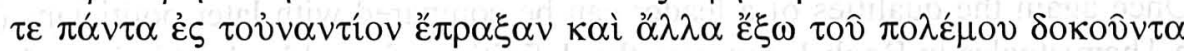

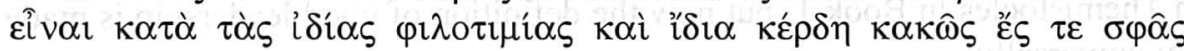

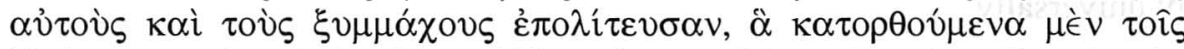

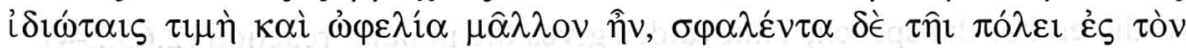

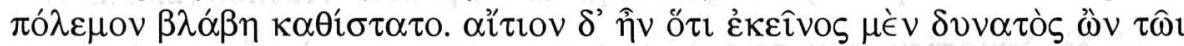

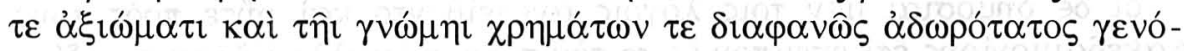

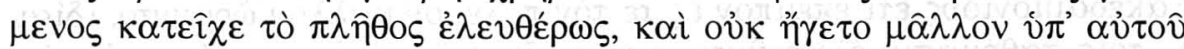

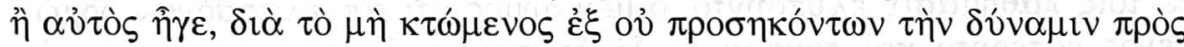

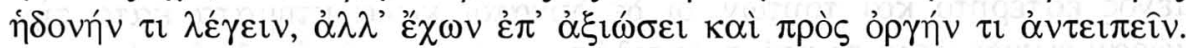

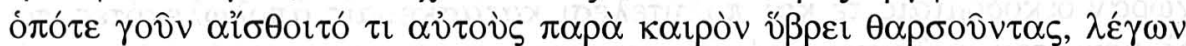

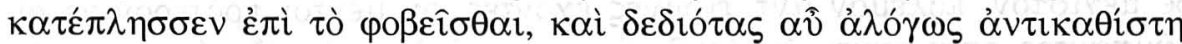

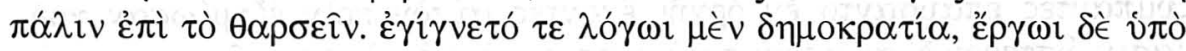

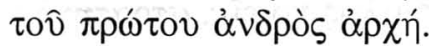

For as long as he was at the head of the state during the peace, he pursued a moderate and conservative policy; and in his time its greatness was at its height. When the war broke out, here also he seems to have rightly gauged the power of his country.

He outlived its commencement two years and six months, and the correctness of his previsions respecting it became better known by his death. He told them to wait quietly, to pay attention to their marine, to attempt no new conquests, and to expose the city to no hazards during the war, and doing

15 See my commentary on Thucydides 2.65 .3 for bibliography. 
this, promised them a favorable result. What they did was the very contrary, allowing private ambitions and private interests, in matters apparently quite foreign to the war, to lead them into projects unjust both to themselves and to their allies- projects whose success would only conduce to the honor and advantage of private persons, and whose failure entailed certain disaster on the country in the war. The causes of this are not far to seek. Pericles indeed, by his rank, ability, and known integrity, was enabled to exercise an independent control over the multitude-in short, to lead them instead of being led by them; for as he never sought power by improper means, he was never compelled to flatter them, but, on the contrary, enjoyed so high an estimation that he could afford to anger them by contradiction. Whenever he saw them unseasonably and insolently elated, he would with a word reduce them to alarm; on the other hand, if they fell victims to a panic, he could at once restore them to confidence. In short, what was nominally a democracy became in his hands government by the first citizen. (transl. Crawley)

Although after this chapter Pericles is never mentioned as a leader again ${ }^{16}$, his shadow obviously falls heavily over the entire rest of the narrative.

\section{Conclusions}

So, we have seen that again and again Pericles' speeches do Thucydides' work for him by introducing major themes and countering earlier false arguments. None of Pericles' speeches is even answered (except for the brief speech of Archidamus in Thucydides 2.10-13, which is a conventional battle-exhortation pair, and where Archidamus is his foil).

Even more important, from the moment he appears to the moment of his death, Pericles completely dominates the narrative. Thucydides is able to limit him to one concentrated period $^{17}$, by introducing him only late in the process of planning for war, and removing him from it nearly a year before he actually died (Sept 429).

Finally, Thucydides closes by having Pericles define his own qualities of greatness, which are explicitly endorsed by the historian and compared favorably to later leaders- the only time Thucydides jumps ahead to the end of the whole war.

Indeed, if one were inclined to an analyst view of Thucydides' narrative of

Only for a technical detail in 6.31 .2 , to indentify a particular military expedition for comparison of ship-numbers.

17 In the same way he concentrates the plague, which actually was spread over several years, to a single passage. 
"early" and "late" passages, one could read 1.138 to 2.65 as a miniature historical essay on Pericles and the Peloponnesian War", with an opening on leadership in the Persian war, and an epilogue comparing Pericles with the inferior leadership that followed him. One might also consider them a sort of mini-biography of Pericles in answer to Stesimbrotus or Plato, a biography more in the sense of Xenophon's encomiastic biographies than any work of Plutarch's.

But in this connection we must think of the old debate over the historical accuracy of Thucydides' speeches (his account of his method in 1.22 is little help, since it is controversial and the source of much disagreement, although I can discuss my opinion of it if there is time). Can it really be that, for the one figure whom Thucydides undoubtedly knew (and heard speak) and admired, and who personally led Athens' war-effort and strategy, Thucydides has taken artistic license in composing his words? Would it not be shocking to find a historian taking such liberties, and treating the facts of Pericles' life as freely (although more admiringly) as the comic writers do?

It would not at least be unexampled, at least for memoirs of a roughly contemporary figure. Socrates was an admired teacher, a great man whose life and death deserved careful remembering; and yet Plato undoubtedly placed Socrates in situations that were historically doubtful, and had him expound ideas that owed more to Plato than to the historical figure. Is Thucydides too a disciple who has used his master's portrait to present his own views? ${ }^{18}$

If Thucydides were a biographer of Pericles, we would certainly find him unsatisfactory: He ignores his rise to power and constitutional changes, but also all the details of his personal life, to create an austere and profoundly serious leader, who consistently tells the same unwelcome truths to a people that receives them differently each time. By modern terms, such license is not only not biographical, it is not even historical.

But a better way of looking at the portrait of Pericles is in terms of Aristotle's criticism of history in the Poetics (1451b):

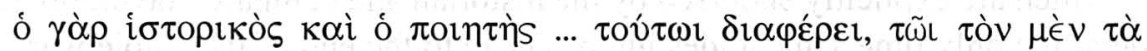

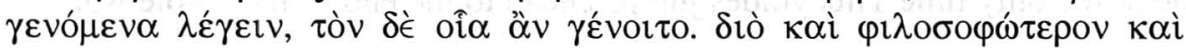

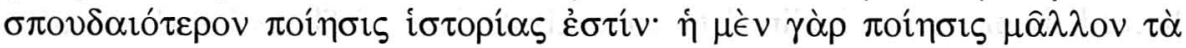

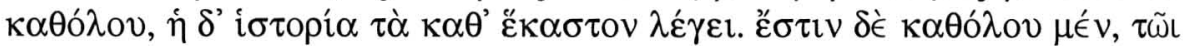

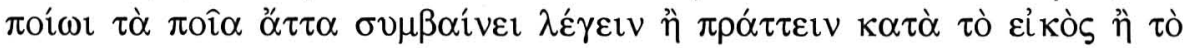

One might also compare the occasional allusions to Socrates' probable fate in Plato to Pericles' and Thucydides' hints about the mistakes Athens in bound to make without Pericles to guide them. 


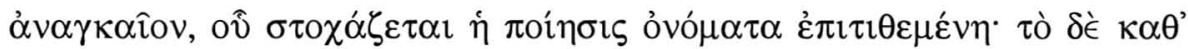

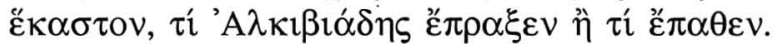

For the historian and the poet...differ in this, that one says things which have happened, the other the sort that could happen. That is why poetry is more serious and more philosophical than history; poetry speaks more of universals, and history of particulars. The universal is, what sort of thing it happens that what sort of person says or does according to probability or necessity, which poetry aims for, although it attaches names; the particular is, what Alcibiades did or what happened to him.

In Pericles, Thucydides finds a dynamic character that transcends its factual historical basis. He deprives him of much of his career and personality, but he gives him universality, the one thing that Aristotle says history needs and that a factual account cannot supply. Thus we learn not what Pericles actually did or what happened to him (as Aristotle thinks we do for Alcibiades) but the sorts of insights and arguments about politics, human society and power, that a Pericles in any age, even our own, might find worth saying over and over again. 


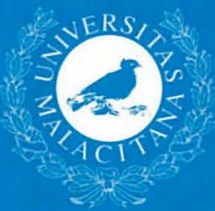

